\title{
Pelatihan Akuntansi Manajemen dan Pemasaran Bagi Pengrajin Perhiasan di Sekarbela
}

\author{
Nurabiah*, Herlina Pusparini, Nur Fitriyah
}

Fakultas Ekonomi dan Bisnis Universitas Mataram, Mataram-Indonesia

\begin{abstract}
Kata Kunci: pengrajin perhiasan, pemasaran, produksi, akuntansi manajemen
\end{abstract}

\begin{abstract}
Abstrak: Sekarbela merupakan sentra kerajinan/industry perhiasan yang ada di pulau Lombok. Mitra pengabdian ini berlokasi di Sekarbela kota Mataram salah satunya Alfin Mutiara. Dalam menghadapi persaingan yang ketat mitra dituntut untuk terus berkreasi dan berinovasi, baik dari segi produksi, manajemen maupun pemasarannya. Sehingga kegiatan pengabdian ini bertujuan 1) aspek produksi, perlu meningkatkan kemampuan dalam mendesain sebuah produk yang up to date agar bisa menyesuaikan selera pasar sehingga bisa meningkatkan permintaan baik pada segmen konsumen yang sudah ada ataupun untuk calon konsumen baru. 2) aspek pemasaran, perlu pengembangan sistem pemasaran yang lebih efektif agar informasi produk, penggunaan pemakaian produk dan harga yang transparan mudah diakses dan memberikan informasi yang lengkap bagi pelanggan maupun calon pelanggan baru. 3) aspek manajemen, perlu meningkatkan kemampuan manajerial mitra dalam hal menghitung harga pokok produksi yang tepat dan dapat mengidentifikasi aktivitas yang tidak bernilai tambah sehingga harga yang ditetapkan merupakan harga yang kompetitif yang bersaing. Metode yang digunakan dalam pengabdian ini antara lain: 1) ceramah bervariasi, metode ini dilakukan di awal pelatihan sebagai pengantar untuk memberikan pengantar dalam mendesain sebuah produk, pengantar pemasaran dan akuntansi manajemen 2) latihan mendesain produk yang up to date, latihan pemasaran lewat media sosial, dan latihan menghitung harga pokok produksi dan penentuan harga jual dengan metode target costing. Pelatihan ini dilaksanakan selama 2 hari dengan 10 orang peserta yang berasal dari pemilik dan karyawan yang ada di kerajinan perhiasan Sekarbela. Hasil pelatihan menunjukkan peserta sangat antusias dengan banyaknya pertanyaan-pertanyaan. Dengan adanya pengabdian ini diharapkan adanya peningakatan kuantitas dan kualitas produk sehingga meningkatkan pendapatan mitra.
\end{abstract}

Korespondensi: nurabiah@unram.ac.id

\section{PENDAHULUAN}

Pemerintah Propinsi NTB telah menempatkan pariwisata sebagai salah satu sektor unggulan utama penggerak perekonomian masyarakat melalui program Visit Lombok Sumbawa 2013 dan 2016 dengan masing-masing target kunjungan 1 juta dan 2 juta wisatawan. (www.ntbprov.go.id). Menurut Ave (2006) yang mengatakan bahwa pariwisata di samping memberikan dampak langsung juga memberikan dampak tidak langsung dan dampak ikutan (induced effect) terhadap perekonomian. Dampak tidak langsung dinikmati oleh karyawan hotel, restoran, biro perjalanan wisata, objek tujuan wisata, sopir angkutan, penerimaan pajak bagi pemerintah, pengrajin cenderamata, seniman, percetakan, pedagang sayur-sayuran dan buah-buahan, pompa bensin, dan sebagainya. 
Salah satu yang mendapatkan keuntungan dari pariwisata adalah pengrajin cendramata dan khususnya pengrajin perhiasan. Daerah yang paling dikenal masyarakat sebagai sentra kerajinan/industri perhiasan di pulau Lombok adalah kelurahan Sekarbela dan lingkungan karang genteng yang berada di lokasi strategis di kota Mataram. Dengan lokasi yang cukup mudah dijangkau baik dari kawasan wisata pantai Senggigi maupun dari lokasi Bandara Internasional Lombok, Sekarbela merupakan destinasi wisata belanja yang paling sering dikunjungi wisatawan. Hampir sebagian penduduk desa Sekarbela dan lingkungan Karang Genteng bermata pencaharian sebagai pengrajin perhiasan dan aksesoris mutiara, dengan toko-toko perhiasan yang tersebar hampir di sepanjang jalan.

Persaingan bisnis yang semakin ketat dikarenakan dampak globalisasi dan diberlakukanya era perdagangan bebas telah menggeser paradigma bisnis dari comparative advantage menjadi competitive advantage, yang memaksa kegiatan bisnis/perusahaan memilih strategi yang tepat. Strategi yang dimaksud adalah dimana perusahaan berada dalam posisi strategis dan bisa beradaptasi dengan lingkungan yang terus berubah. Begitu juga yang harus dilakukan oleh para pengrajin perhiasan di Sekarbela dan Karang Genteng khususnya dituntut untuk terus berkreasi dan berinovasi, baik dari segi produksi, manajemen maupun pemasarannya.

Tetapi tidak semua pengrajin perhiasan ini memperhatikan hal tersebut, contohnya mitra pengabdian ini yaitu Alfin Mutiara. Dalam hal menentukan harga pokok produksi masih menggunakan cara yang tradisional yaitu dengan menggunakan cost plus price method dimana dengan menggunakan metode ini dalam menentukan margin terlalu tinggi dan tidak dapat mengidentifikasi aktivitas yang tidak bernilai tambah sehingga dampaknya yaitu penentuan harga jualnya tidak kompetitif. Hal ini terjadi karena banyaknya jenis perhiasan seperti mutiara, emas, perak, rhodium, sehingga untuk menentukan harga produksi mengalami kesulitan yang dialami kedua mitra.

Selain itu masalah kedua mitra masih menggunakan teknologi yang sangat sederhana dalam pengolahan dan pendistribusian komoditas mereka. Padahal kemungkinan pengembangan usaha ini sangat besar, dengan potensi hasil yang tidak sedikit. Dari hasil observasi terlihat kurangnya pengetahuan pengrajin akan perkembangan mode, tekhnik pengolahan, dan selera konsumen, menyebabkan banyak konsumen komplain. Mulai dari masalah model yang tidak variatif, hingga kerapian pengerjaan suatu produk. Hal ini terjadi karena belum adanya contoh desin yang up to date yang dimiliki kedua mitra agar bisa menyesuaikan produk dengan selera dan permintaan konsumen, baik pada segmen konsumen yang sudah ada ataupun untuk calon konsumen baru.

Kerajinan perhiasan ini khususnya mutiara memiliki pelanggan yang tersebar di banyak daerah di Indonesia. Pelanggannya bukan saja dari wilayah NTB, juga banyak yang berasal dari luar daerah maupun manca negara. Awalnya mereka mengenal perhiasan khususnya mutiara ini pada saat melakukan wisata ke pulau Lombok. Tetapi setelah mereka kembali ke daerahnya masing-masing, mereka bingung bagaimana cara memesan kembali barang tersebut. Pemesanan bisa saja dilakukan via telepon tetapi bagaimana cara melihat produk tersebut itu akan menjadi hambatan. Akibatnya, penjual akan kesulitan untuk memperluas pangsa pasar dan ini tidak ekonomis. Hal ini terjadi karena belum adanya system pemasaran yang efektif dan belum adanya informasi yang lengkap tentang model-model perhiasan, 
pengunaan pemakaian perhiasan dan belum transparannya dalam menentukan harga jual di tiap-tiap perhiasan.

Melalui kegiatan ini diharapkan diharapkan akan meningkatkan pendapatan pengrajin perhiasan kedua mitra di Sekarbela dan Karang Genteng dengan harapan akan meningkatkan kuantitas dan kualitas produk sehingga akan meningkatkan omzet kedua mitra. Berdasarkan permasalahan tersebut maka perlu dilakukan pelatihan yang bertujuan untuk (a) aspek produksi, perlu untuk meningkatkan kemampuan dalam mendesain sebuah produk yang up to date agar bisa menyesuaikan selera pasar sehingga bisa meningkatkan permintaan baik pada segmen konsumen yang sudah ada ataupun untuk calon konsumen baru. Untuk itu diperlukan contoh-contoh desain yang up to date bagi kedua mitra, (b) aspek pemasaran, perlu pengembangan sistem pemasaran yang lebih efektif agar informasi produk, penggunaan pemakaian produk dan harga yang transparan mudah diakses dan memberikan informasi yang lengkap bagi pelanggan maupun calon pelanggan baru. Untuk itu diperlukan sebuah pemasaran lewat media social, (c) aspek manajemen, perlu meningkatkan kemampuan manajerial kedua mitra dalam hal menghitung harga pokok produksi yang tepat dan dapat mengidentifikasi aktivitas yang tidak bernilai tambah sehingga harga yang ditetapkan merupakan harga yang kompetitif yang bersaing. Untuk itu diperlukan metode yang tepat yaitu dengan menggunakan metode "target costing".

\section{METODE KEGIATAN}

Untuk pemecahan permasalahan mitra terkait dengan aspek manajemen, produksi, dan pemasaran, maka hal-hal yang akan dilaksanakan pada kegiatan pengabdian masyarakat ini antara lain:

Solusi dari permasalahan mitra yang pertama adalah terkait dengan manajemen, tim akan membekali mitra dengan pengetahuan, pelatihan, dan pendampingan tentang perhitungan harga pokok produksi dengan menggunakan metode target costing. Untuk pelatihan akan dilakukan dengan metode praktek perhitungan langsung agar kedua mitra bisa mempraktekkan langsung apa yang sudah dilatih. Solusi dari permasalahan mitra yang kedua adalah terkait dengan produksi, tim akan membekali mitra dengan pengetahuan dan pendampingan dalam hal mendesain model-model perhiasan yang up to date yang bisa didapatkan dari berbagai sumber, salah satunya dari internet. Solusi dari permasalahan mitra yang ketiga adalah terkait dengan pemasaran, tim akan membekali mitra dengan pengetahuan dasar yang cukup dan kegiatan dilanjutkan dengan pendampingan dalam pemasaran dengan menggunakan media social.

Kemudian, selama dua bulan pertama setelah pelatihan dan pendampingan tim pengabdian akan terus memonitoring aktivitas manajemen, produksi, dan pemasarannya yang dilakukan mitra untuk mengetahui kelemahan serta permasalahan yang dihadapi mitra. Apabila muncul permasalahan baru, maka tim akan mencari solusi bersama-sama dengan mitra.Selama kegiatan pengabdian berlangsung, kedua mitra diharapkan selalu ikut berpartisipasi secara aktif. Partisipasi kedua mitra yang diharapkan selama kegiatan yaitu meliputi: berusaha mampu memahami permasalahannya sendiri, berusaha mampu mengenali kebutuhan nyata yang berkaitan dengan usahanya yang diperlukan, berusaha mencari solusi guna memecahkan permasalahannya, berusaha mengenali desain-desain motif perhiasan yang 
laris dipasaran sesuai dengan kelas konsumennya masing-masing, ikut memilih dan menentukan desain-desain baru yang akan diproduksinya, menyediakan fasilitas tempat kegiatan, bersedia membenahi manajemen usahanya, dan ikut memasarkan produk perhiasan yang baru.

\section{HASIL DAN PEMBAHASAN}

Sebelum membahas hasil yang sudah dicapai dalam rangkaian kegiatan pengabdian kepada masyarakat ini, beberapa hal konsep yang sudah dibahas antara lain:

\section{A. Harga Pokok produksi}

Harga Pokok Produksi Menurut Hansen dan Mowen (2006), harga pokok produksi mencerminkan total biaya barang yang diselesaikan selama periode berjalan. Biaya yang dibebankan ke barang yang diselesaikan adalah biaya bahan langsung, biaya tenaga kerja langsung, dan biaya overhead. Setiap perusahaan akan berusaha untuk mendapatkan laba yang merupakan selisih dari jumlah pendapatan dengan biaya-biaya yang dikeluarkan perusahaan. Perhitungan harga pokok produksi yang tepat dan teliti sangat penting. Kesalahan perhitungan harga pokok produksi akan berakibat buruk bagi perusahaan.

Fungsi harga pokok produksi antara lain: 1) sebagai dasar penetapan harga jual di pasar 2) menyediakan informasi bagi manajemen untuk menetapkan target dan operasi menuju sasaran akhir yang menjadi tujuan perusahaan 3) sebagai penentu efektivitas kinerja perusahaan.

Unsur- unsur Harga Pokok produksi

a. Biaya Bahan Baku

Bahan baku merupakan bahan yang dapat diidentifikasikan secara langsung dengan produk yang dihasilkannya, nilainya relative besar, dan umumnya sifat bahan baku masih melekat pada produk yang dihasilkannya.

b. Biaya Tenaga Kerja

Definisi tenaga kerja adalah harga yang dibebankan untuk penggunaan tenaga kerja manusia tersebut. (Mulyadi, 2001:343) istilah biaya tenaga kerja digunakan untuk pembayaran kompensasi kepada tenaga kerja yang bekerja dalam fungsi produksi, fungsi pemasaran, dan fungsi administrasi umum. Biaya tenaga kerja pada fungsi produksi diklasifikasikan atas biaya tenaga kerja langsung dan biaya tenaga kerja tidak langsung

c. Biaya Overhead Pabrik

Biaya overhead pabrik merupakan biaya bahan tidak langsung, biaya tenaga kerja tidak langsung dan semua biaya pabrik lainnya yang tidak dapat dibebankan langsung ke produk. Menurut Sidharta danYessica (2008) selain itu juga biaya overhead pabrik adalah termasuk seluruh biaya yang tidak termasuk dalam bahan langsung dan tenaga kerja langsung. Biaya overhead pabrik termasuk bahan tidak langsung, tenaga kerja tidak langsung, pemeliharaan dan perbaikan peralatan produksi, listrik dan penerangan, pajak properti, depresiasi, dan asuransi fasilitas produksi.

\section{B. Target Costing}

Menurut Supriyono (2002), target costing adalah suatu sistem untuk mendukung proses pengurangan biaya dalam tahap penetapan harga jual, penetapan harga jual adalah 
proses penentuan apa yang akan diterima suatu perusahaan dalam penjualan produknya. (Grifin dan Ebert, 2007:20). Target Costing adalah suatu metode penentuan biaya produk atau jasa yang didasarkan pada harga (target price) yang diperkirakan dapat diterima oleh konsumen (Mulyadi, 2007:421).

\section{Prinsip-prinsip Bagi Penerapan Target Costing}

a. Price Led Costing

Target price (competitive market price) akan mempengaruhi target cost dengan mengeluarkan target profit dari target price. Target price dikendalikan oleh situasi di pasar dan target profit ditentukan oleh efektivitas pengelolaan keuangan perusahaan dan industrinya sehingga target costing menunjukkan standar pergerakan pasar (market driven standard), yaitu harga pasar kompetitif dikurangi dengan target laba sama dengan target biaya (harga pokok) yang diperkenankan.

b. Focus On Customer

Pengembangan produk dilakukan apabila produk tersebut memenuhi harapan pelanggan. Harapan pelanggan atas kualitas, biaya, dan waktu secara simultan diintegrasikan kedalam keputusan produk, proses dan mengarahkan ke analisis biaya.

c. Focus On Design And Life Cycle Orientation

Sistem target costing mempertimbangkan prancangan produk dan proses sebagai focus terhadap manajemen biaya. Pengaruh perancangan atas biaya dari penelitian dan pengembangan sampai dispotition yang memungkinkan upaya pengurangan biaya sepanjang siklus hidup suatu produk secara keseluruhan.

d. Cross Functional Involvement

Target costing melibatkan pihak intern dan ekstern secara lintas fungsi, mulai dari bagian riset dan pengembangan, desain dan rekayasa, produksi, pemasaran, pengadaan bahan, akutansi biaya, jasa dan pendukung sampai dengan pelanggan, diler distributor dan penyedia jasa purna jual.

e. Value Chain Involvement

Target costing mengembangkan usaha pengurangan biaya sepanjang lantai nilai dengan mengembangkan hubungan kerja sama jangka panjang dengan seluruh bagian perusahaan yang diperluas termasuk dengan pemasok dan pelanggan.

Adapun tahapan yang telah dilakukan dalam pelatihan ini adalah sebagai berikut :

1. Tahap Perencanaan Pengabdian

Pada tahap ini, berdasarkan investigasi awal, tim pengabdi menganalisis mengenai kebutuhan-kebutuhan apa yang digunakan dalam pengabdian ini. Selain itu adanya kekurangan pemahaman tentang penentuan harga, mencari aplikasi contoh desain perhiasan yang ada di play store.

2. Tahap Pelaksanaan Pengabdian

\section{a. Tahap I}

Tahap I ini, kegiatan yang dilakukan dengan berbincang-bincang kepada peserta mengenai arti pentingnya penetapan harga jual, cara pemasaran dengan menggunakan media social dan cara penulusuran desain-desain yang ada di play store. Dari hasil 
wawancara/bincang-bincang tersebut dapat menjadi tolak ukur keberhasilan pelatihan ini. Sebagian peserta memberikan jawaban bahwa kegiatan ini bahwa kegiatan ini sangat bermanfaat, baik dilihat dari aspek materi, maupun ketika pelatihan.
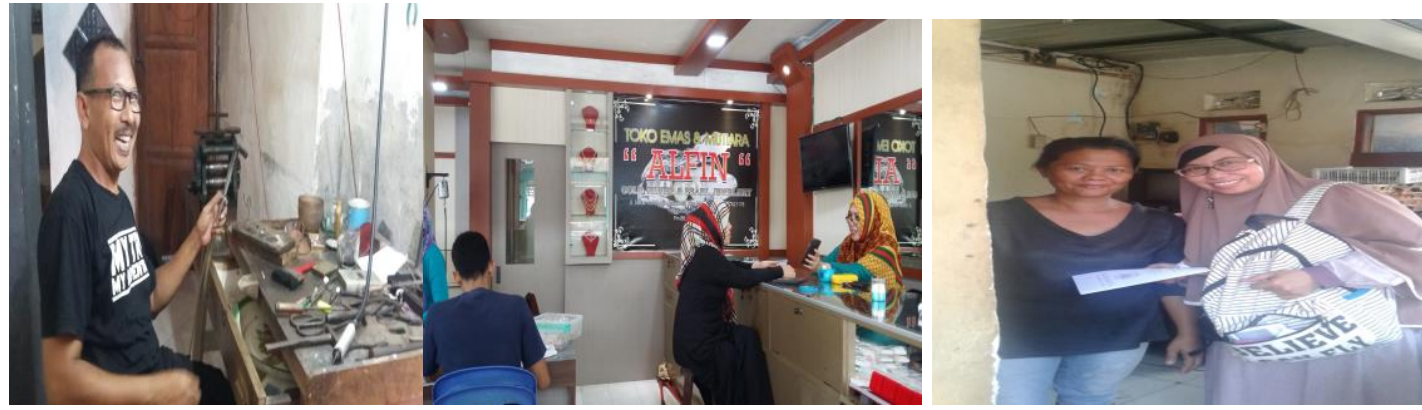

b. Tahap II

Melakukan pendampingan dalam menghasilkan beberapa hal, antara lain:

(1) Beberapa aplikasi contoh-contoh desain perhiasan yang up to date

Aplikasi contoh desain ini bisa didapatkan dari beberapa aplikasi yang ada di play store ataupun di google. Ada banyak aplikasi yang bias ditemukan, antara lain:

a. Terbaru desain jewelry emas e. Jewelry designs

b. Desain perhiasan cincin f. Desain gelang emas

c. Desain perhiasan anting g. Jewellery design collection

d. Desain perhiasan emas h. Ide desain perhiasan

(2) Format penentuan harga jual dengan metode target costing

(a) Menentukan harga pasar menurut Blocher et al $(2000 ; 170)$ dengan riset pasar yang terdiri dari dari riset tentang harga produk pesaing dan kemampuan membeli konsumen agar bisa diterima pasar.

(b) Menentukan laba yang diharapkan.

(c) Mark up $=($ laba tertinggi- - -iaya tetap dan variable $) /$ laba tertinggi $x 100 \%$

(d)Menentukan perhitungan target biaya produk yang dilakukan dengan rumus :

Target Costing $=$ harga pasar - laba yang diinginkan .

(e)Menggunakan rekayasa nilai ( value engineering) untuk mengidentifikasi cara yang dapat menurunkan kos produk menurut Blocher et al $(2000 ; 170)$

Penghematan = biaya sebelumnya - biaya sesudahnya

(3) Pemasaran produk dengan menggunakan media social

Contoh pemasarannya menggunakan FB, Istagram, membuat blog, membuat website, mencari web hosting yang tersedia. 

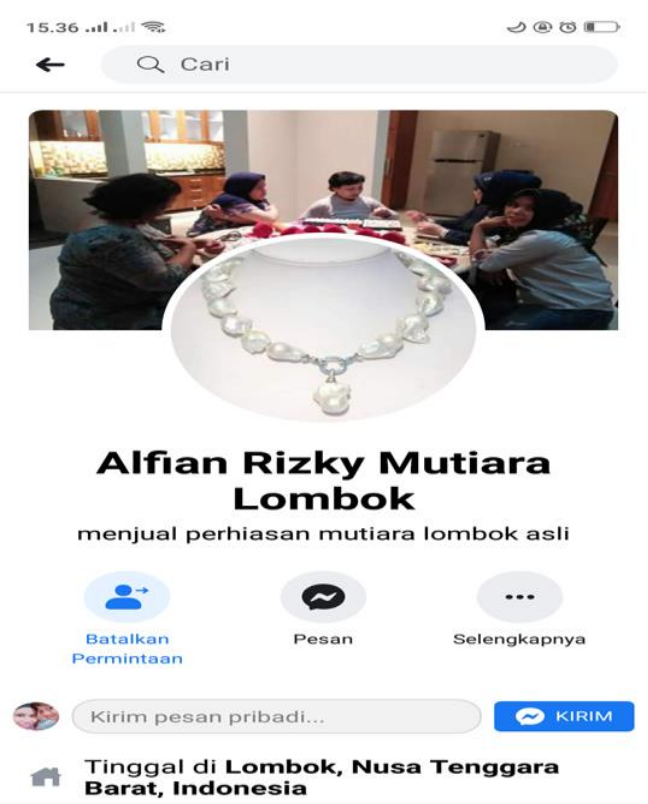

3. Tahap Evaluasi Kegiatan

Adapun pada tahap evaluasi kegiatan adalah sebagai berikut :

Tabel 1. Tolak Ukur Pelaksanaan

\begin{tabular}{|c|c|c|}
\hline Tujuan & Indikator Capaian & Tolak Ukur \\
\hline $\begin{array}{l}\text { Peserta memiliki kemampuan dalam } \\
\text { mendesain produk yang up to date } \\
\text { agar bisa menyesuaikan selera pasar } \\
\text { sehingga bisa meningkatkan } \\
\text { permintaan baik pada segmen } \\
\text { konsumen yang sudah ada ataupun } \\
\text { untuk calon konsumen baru. Selain } \\
\text { itu peserta bisa menghasilkan } \\
\text { inovasi-inovasi keragaman dalam } \\
\text { membuat produk. }\end{array}$ & $\begin{array}{l}\text { Peserta mampu } \\
\text { mendesain dan } \\
\text { menyediakan produk } \\
\text { baru yang diinginkan } \\
\text { oleh konsumen dengan } \\
\text { melihat contoh-contoh } \\
\text { desain yang tersedia di } \\
\text { media sosial }\end{array}$ & $\begin{array}{l}\text { Peserta menyadari } \\
\text { pentingnya desain-desain } \\
\text { yang up to date agar bisa } \\
\text { bersaing di pasaran }\end{array}$ \\
\hline $\begin{array}{l}\text { Peserta mampu mengatasi kesulitan } \\
\text { akses antara mitra dengan konsumen. } \\
\text { Dimana informasi penggunaan } \\
\text { pemakaian produk dan harga yang } \\
\text { transparan mudah diakses dan } \\
\text { memberikan informasi yang lengkap } \\
\text { bagi pelanggan maupun calon } \\
\text { pelanggan baru. }\end{array}$ & $\begin{array}{lr}\text { Peserta } & \text { mampu } \\
\text { menyediakan } & \text { akses } \\
\text { berupa akses } & \text { di media } \\
\text { social } & \text { sehingga } \\
\text { konsumen } & \text { memiliki } \\
\text { informasi } & \text { tentang } \\
\text { produk } & \text { beserta } \\
\text { harganya } & \\
\end{array}$ & $\begin{array}{lr}\text { Peserta } & \text { menyadari } \\
\text { pentingnya keterbukaan agar } \\
\text { konsumen gampang } \\
\text { mengakses informasi- } \\
\text { informasi yang dibutuhkan } \\
\text { konsumen tersebut }\end{array}$ \\
\hline $\begin{array}{l}\text { Peserta memiliki kemampuan dalam } \\
\text { hal menghitung harga pokok } \\
\text { produksi yang tepat dan dapat } \\
\text { mengidentifikasi aktivitas yang tidak } \\
\text { bernilai tambah sehingga harga yang } \\
\text { ditetapkan merupakan harga yang } \\
\text { kompetitif yang bersaing dengan } \\
\text { menggunaka metode "target costing". }\end{array}$ & $\begin{array}{l}\text { Peserta mampu } \\
\text { menghitung harga } \\
\text { pokok produksi dengan } \\
\text { metode target costing }\end{array}$ & $\begin{array}{l}\text { Peserta mampu menentukan } \\
\text { harga yang tepat agar bisa } \\
\text { berkompetensi dengan } \\
\text { pedagang lainnya }\end{array}$ \\
\hline
\end{tabular}




\section{KESIMPULAN DAN SARAN}

\section{Kesimpulan}

1. Melalui pelatihan ini diharapkan para peserta (pemilik / manajemen dan karyawannya) sudah bisa mendesain produk-produk yang terbaru, bisa menghitung harga jual dengan metode target costing dan bisa memasarkan produknya lewat media sosial sehingga lebih siap dalam menghadapi persaingan yang semakin ketat dan bisa meningkatkan pendapatan.

2. Ada beberapa faktor-faktor pendorong dan penghambat pelaksanaan pelatihan akuntansi manajemen dan pemasaran bagi pengrajin perhiasan di Sekarbela, yaitu : (a) Faktor Pendorong terdiri dari terjalinnya kerjasama antara tim pengabdian dengan bapak/ibu pengrajin perhiasan di Sekarbela dan selama pelaksanaan kegiatan pelatihan di Sekarbela ini seluruh peserta memberikan apresiasi yang baik. Peserta secara aktif mengikuti kegiatan pelatihan akuntansi manajemen dan pemasaran dari awal hingga akhir, hal ini ditunjukkan dengan banyaknya peserta yang bertanya. (b) Faktor penghambat yaitu sulitnya menentukan jadwal pertemuan antara tim pengabdian dengan bapak/ibu pengrajin perhiasan karena kesibukan dalam menjalankan usaha mereka. Sehingga tim pengabdian melakukan pelatihan secara satu-satu di tempat usaha atau dagang mereka. Tetapi secara keseluruhan tidak ada hambatan yang terlalu teknis maupun administratif.

\section{Saran}

Mengingat peserta yang mendapat kesempatan mengikuti pelatihan ini terbatas dan bukanlah hal yang mudah maka perlu adanya upaya untuk melanjutkan kegiatan pelatihan serta perlu adanya pembimbingan secara berkelanjutan untuk mendapatkan hasil yang optimal. Disamping itu untuk kegiatan selanjutnya diperlukan dana yang lebih besar.

\section{Ucapan Terima Kasih}

Penulis mengucapkan terima kasih kepada seluruh FEB Unram, tim pengabdian dan para peserta pelatihan ini khususnya pemilik toko "Alfian Mutiara" yang telah memberi dukungan financial dan moril sehingga bisa terlaksana pengabdian ini.

\section{DAFTAR PUSTAKA}

Ave, Joop, 2006. Peran Strategis Sektor Pariwisata Dalam Pembangunan Ekonomi Nasional. Makalah disampaikan pada acara Seminar dan Diskusi terfokus ISEI: Sektor Jasa sebagai Motor Penggerak Ekonomi Daerah, pada tanggal 18 Mei 2006, Denpasar.

Blocher, Chen dan Lin. 2000. Manajemen Biaya. Edisi 1. Jakarta:Salemba

Griffin, ricky W dan Ebert, Ronan J. 2007. Bisnis. Edisi 8, Jakarta: Erlangga

Hansen,Don R. dan Mowen, M. Maryanne M. Mowen. 2006. Akuntansi Manajemen, Jilid 2, Edisi Keenam, Erlangga, Jakarta.

Himawan, Agung, F. dan Pendajay, Riki. 2005. Penerapan Metode Target Costing sebagai Alat Bantu Manajemen dalam Mengoptimalkan Perencanaan Laba (Studi Kasus PT XYZ). ESENSI, Volume 8 No. 2/2005 
Mulyadi, 2001. Akuntansi Manajemen: Konsep, Manfaat, dan Rekayasa. Edisi 3. Jakarta: Salemba Empat

Mulyadi, 2007. Sistem Perencanaan dan Pengendalian Manajemen, Jakarta: Salemba Empat Supriyono. 2002. Akuntansi Biaya: Pengumpulan Biaya dan Penentuan Harga Pokok. Edisi 2, Yogyakarta: BPGE-Yogyakarta

www.maxmanroe.com

www.ntbprov.go.id

www.zalora.com. 